\title{
ROLE OF FORCED DIURESIS IN MANAGEMENT OF URINARY CALCULI: AN OBSERVATIONAL STUDY
}

\author{
Bajrang Tak ${ }^{1}$, Gajendra Anuragi ${ }^{2}$, Dinesh Chandra Sharma ${ }^{3}$, Jaspreet Singh ${ }^{4}$, Durgawati ${ }^{5}$, Rachna Gupta ${ }^{6}$ \\ ${ }_{1}^{1}$ Assistant Professor, Department of General Surgery, SMS Medical College, Jaipur. \\ ${ }^{2} 3^{\text {rd }}$ Year Junior Resident, Department of General Surgery, SMS Medical College, Jaipur. \\ ${ }^{3}$ Medical Officer, Department of General Surgery, SMS Medical College, Jaipur. \\ ${ }_{4}^{4} 2^{\text {nd }}$ Year Junior Resident, Department of General Surgery, SMS Medical College, Jaipur. \\ $53^{\text {rd }}$ Year Junior Resident, Department of Physiology, SMS Medical College, Jaipur. \\ ${ }^{6}$ Associate Professor, Department of General Surgery, SMS Medical College, Rewa, Madhya Pradesh.
}

\begin{abstract}
Urolithiasis is a common problem in general population. It is treated conservatively as well as surgically. Aim of this study is to see the effects of forced diuresis in relieving acute symptoms or descent of ureteric stone or passing of stone. Study was done on 207 cases of all age group selected by simple method with symptoms of pain, burning micturition, increased frequency, haematuria, etc. In our study forced diuresis given in all 207 patients and after giving treatment, relief in symptoms, any descent or passage of urinary stone or any changes in urine routine and microscopic examination was noted and compared. In this study, symptomatic relief and gradual decline in pus cells was found in most of the cases with renal calculi, vesical calculi, ureter calculi and uretheral and multiple sites of urinary tract system. In most of the ureteric calculi, it worked as a definitive treatment as stone passed out in most of these cases. In this study author concluded that in acute symptomatic patients, relief can be obtained by forced diuresis and then patient can be planned for elective management.
\end{abstract}

\section{KEYWORDS}

Urolithiasis, Forced Diuresis, Renal Calculi, Ureteric Calculi, Vesical Calculi, Urethral Calculi.

HOW TO CITE THIS ARTICLE: Bajrang Tak, Gajendra Anuragi, Dinesh Chandra Sharma, Jaspreet Singh, Durgawati, Rachna Gupta. "Role of Forced Diuresis in Management of Urinary Calculi: An Observational Study." Journal of Evolution of Medical and Dental Sciences 2015; Vol. 4, Issue 100, December 14; Page: 16573-16579, DOI: 10.14260/jemds/2015/2468

\section{INTRODUCTION}

Urolithiasis is one of the oldest known disease affecting the human beings. Management of urinary calculi depends on location and size of calculi. The small stones of size $<4 \mathrm{~mm}$ in the lower half of the ureter usually pass spontaneously in $93 \%$ of cases. Medium sized stones (4-6mm) of ureter can pass spontaneously in $50 \%$ cases. Large stones $(>6 \mathrm{~mm})$ in ureter usually retains at the natural narrowing. Smaller stone can be force to descent down by diuresis using plenty of water intake or its expulsion can be facilitated by various modalities like forced diuresis, antispasmodics, antiinflammatory drugs and smooth muscle relaxants.

\section{AIMS AND OBJECTIVES}

- To study various methods for treatment of urinary calculi at different sites.

- To evaluate the effect of forced diuresis in relieving acute symptoms or descent of ureteric stone or passing of stone.

\section{MATERIAL AND METHODS}

The present study was carried out in 207 patients of urinary calculi, who were admitted in Surgical Wards of Sanjay Gandhi Memorial Hospital associated with Shyam Shah Medical College, Rewa (M.P.) India, during the period from July 2011 to June 2012.

Financial or Other, Competing Interest: None.

Submission 02-11-2015, Peer Review 03-11-2015,

Acceptance 05-12-2015, Published 14-12-2015.

Corresponding Author:

Dr. Bajrang Tak,

\#169, Frontier Colony, Adarsh Nagar,

Raja Park, Jaipur,

Rajasthan.

E-mail: drbajrangtak@rediffmail.com

DOI:10.14260/jemds/2015/2468
The patients admitted in Surgery ward with the symptoms of pain in abdomen, burning in micturition, frequency of micturition, dribbling or weak stream of urine, retention of urine, haematuria and other symptoms of uremia, signs such as distension of bladder or abdominal tenderness were admitted in surgical wards as provisional diagnosed cases of urinary calculus and were subjected to investigations including routine $\mathrm{Hb} \%$, TLC, DLC, urine analysis, renal function test, X-ray KUB region, USG and intravenous pyelography as and when required. Treatment carried out depending on location and size of urinary calculi either conservatively or surgically.

\section{CONSERVATIVE TREATMENT}

In adults 2 units of fluid (Ringer Lactate) was given intravenously continuously over a period of 2 hours along with 1 ampule of IV Hyoscine Butylbromide (20mg) and 2 ampules of IV Furosemide (40mg).

In children $(<14$ years) the dosage are: Ringer Lactate $50 \mathrm{ml} / \mathrm{kg}$, IV Furosemide $1 \mathrm{mg} / \mathrm{kg}$, IV Hyoscine Butylbromide $5 \mathrm{mg}$ for 0-6 years old and $10 \mathrm{mg}$ for 6-14 years old. Progesterone $(500 \mathrm{mcg})$ given which act as smooth muscle relaxant to prove the descent of stone (Mandar Tilak, et al. 2012). ${ }^{1}$

Three cycles of such therapy was given for 3 consecutive days. After each cycle the patients were interrogated for the relief in their symptoms like pain, burning micturition or haematuria and were clinically examined. After each cycle, urine routine and microscopic examination was done and changes in reaction of urine and number of pus cells was noted. X-ray KUB was taken in some patients after giving forced diuresis and compared with the previous ones and descent of urethral calculus if any was noted. 


\section{MECHANISM}

The IV fluids administration increases the quantity of urine formation. Hyoscine Butyl Bromide relaxes the smooth muscles of ureter and Furosemide forcefully pushes the increased amount of urine down the relaxed ureter, which causes flushing of the whole urinary tract and decreases the acute symptoms like pain, burning micturition and haematuria. Also in some patients the ureteric calculus descents down or passes out after such therapy.

\section{Hyoscine Butylbromide}

It is a semisynthetic anticholinergic drug, which has smooth muscle relaxing property.

\section{Furosemide}

It is a high efficacy diuretic and is a inhibitor of $\mathrm{Na}^{+} \mathrm{K}^{+} 2 \mathrm{Cl}-$ cotransport at thick ascending limb of loop of Henle.

\section{SURGICAL TREATMENT}

sssBy Suprapubic Cystolithotomy, Pyelolithotomy, Nephrolithotomy, Nephrectomy.

\section{OBSERVATIONS}

Findings were analyzed and following observations were recorded.

\begin{tabular}{|c|c|c|c|c|c|c|c|c|c|c|c|c|c|}
\hline \multirow{3}{*}{$\begin{array}{l}\text { Sl. } \\
\text { No. }\end{array}$} & \multirow{3}{*}{$\begin{array}{c}\text { Age } \\
\text { Groups } \\
\text { (In yrs) }\end{array}$} & \multicolumn{4}{|c|}{ Upper Urinary Tract } & \multicolumn{4}{|c|}{ Lower Urinary Tract } & \multirow{2}{*}{\multicolumn{2}{|c|}{$\begin{array}{c}\text { Multiple } \\
\text { Sites }\end{array}$}} & \multirow{3}{*}{ Total } & \multirow{3}{*}{$\%$} \\
\hline & & \multicolumn{2}{|c|}{ Kidney } & \multicolumn{2}{|c|}{ Ureter } & \multicolumn{2}{|c|}{ Bladder } & \multicolumn{2}{|c|}{ Urethra } & & & & \\
\hline & & No. & $\%$ & No. & $\%$ & No. & $\%$ & No. & $\%$ & No. & $\%$ & & \\
\hline 1 & 0 to 10 & 1 & 0.48 & 0 & - & 26 & 12.56 & 1 & 0.48 & 2 & 0.96 & 30 & 14.49 \\
\hline 2 & 11 to 20 & 13 & 6.28 & 5 & 2.41 & 9 & 4.34 & 1 & 0.48 & 2 & 0.96 & 30 & 14.49 \\
\hline 3 & 21 to 30 & 20 & 9.66 & 8 & 3.86 & 9 & 4.34 & 0 & - & 6 & 2.89 & 43 & 20.77 \\
\hline 4 & 31 to 40 & 16 & 7.72 & 3 & 1.44 & 12 & 5.79 & 2 & 0.96 & 4 & 1.93 & 37 & 17.87 \\
\hline 5 & 41 to 50 & 5 & 2.41 & 2 & 0.96 & 13 & 6.28 & 0 & - & 2 & 0.96 & 22 & 10.62 \\
\hline 6 & 51 to 60 & 2 & 0.96 & 3 & 1.44 & 5 & 2.41 & 2 & 0.96 & 5 & 2.41 & 17 & 8.21 \\
\hline 7 & $>60$ & 5 & 2.41 & 4 & 1.93 & 14 & 6.76 & 1 & 0.48 & 4 & 1.93 & 28 & 13.52 \\
\hline & Total & 62 & 29.95 & 25 & 12.07 & 88 & 42.52 & 7 & 3.38 & 25 & 12.08 & 207 & 100 \\
\hline
\end{tabular}

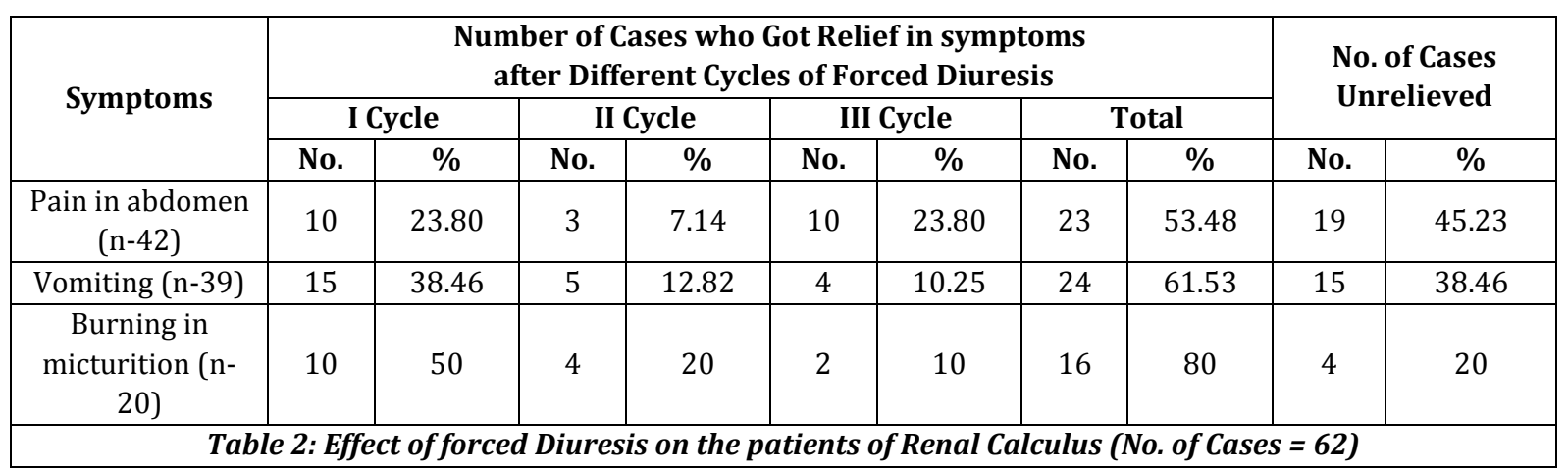

\begin{tabular}{|c|c|c|c|c|c|c|c|c|}
\hline \multirow{2}{*}{ Symptoms } & \multicolumn{8}{|c|}{$\begin{array}{c}\text { Number of Cases who Got Relief in symptoms after } \\
\text { Different Cycles of Forced Diuresis }\end{array}$} \\
\cline { 2 - 9 } & \multicolumn{2}{|c|}{ I Cycle } & II Cycle & \multicolumn{1}{|c|}{ III Cycle } & \multicolumn{2}{c|}{ Total } \\
\cline { 2 - 9 } & No. & $\%$ & No. & $\%$ & No. & $\%$ & No. & $\%$ \\
\hline Pain in abdomen (n-20) & 06 & 30.0 & 06 & 30.0 & 05 & 25.0 & 17 & 85.0 \\
\hline Vomiting (n-16) & 08 & 50.0 & 04 & 25.0 & 02 & 12.50 & 14 & 87.50 \\
\hline Burning in micturition (n-9) & 04 & 44.44 & 02 & 22.22 & 01 & 11.11 & 07 & 77.77 \\
\hline
\end{tabular}

\begin{tabular}{|c|c|c|c|c|c|c|c|c|c|c|}
\hline \multirow{3}{*}{ Symptoms } & \multicolumn{8}{|c|}{$\begin{array}{c}\text { Number of Cases who Got Relief in symptoms after } \\
\text { Different Cycles of Forced Diuresis }\end{array}$} & \multirow{2}{*}{\multicolumn{2}{|c|}{$\begin{array}{c}\text { No. of Cases } \\
\text { Unrelieved }\end{array}$}} \\
\hline & \multicolumn{2}{|c|}{ I Cycle } & \multicolumn{2}{|c|}{ II Cycle } & \multicolumn{2}{|c|}{ III Cycle } & \multicolumn{2}{|c|}{ Total } & & \\
\hline & No. & $\%$ & No. & $\%$ & No. & $\%$ & No. & $\%$ & No. & $\%$ \\
\hline Frequency of Micturition (n-82) & 15 & 18.29 & 9 & 10.97 & 10 & 12.19 & 34 & 41.46 & 48 & 58.53 \\
\hline Burning in micturition (n-78) & 18 & 23.07 & 20 & 25.64 & 15 & 19.23 & 53 & 67.94 & 25 & 32.05 \\
\hline Stream (n-68) & 4 & 5.82 & 4 & 5.82 & 4 & 5.82 & 12 & 17.64 & 56 & 82.35 \\
\hline Pain in abdomen (n-44) & 11 & 25 & 6 & 13.63 & 18 & 40.90 & 35 & 79.54 & 8 & 18.18 \\
\hline Haematuria (n-18) & 14 & 77.77 & 2 & 11.11 & 2 & 11.11 & 18 & 100 & 0 & - \\
\hline Table 4: Effect of fo & $D i$ & siso & $e P c$ & ents o & esi & Calcu & (No. & ases & & \\
\hline
\end{tabular}




\begin{tabular}{|c|c|c|c|c|c|c|c|c|c|c|}
\hline \multirow{3}{*}{ Symptoms } & \multicolumn{8}{|c|}{$\begin{array}{c}\text { Number of Cases who Got Relief in symptoms } \\
\text { after Different Cycles of Forced Diuresis }\end{array}$} & \multirow{2}{*}{\multicolumn{2}{|c|}{$\begin{array}{l}\text { No. of Cases } \\
\text { Unrelieved }\end{array}$}} \\
\hline & \multicolumn{2}{|c|}{ I Cycle } & \multicolumn{2}{|c|}{ II Cycle } & \multicolumn{2}{|c|}{ III Cycle } & \multicolumn{2}{|c|}{ Total } & & \\
\hline & No. & $\%$ & No. & $\%$ & No. & $\%$ & No. & $\%$ & No. & $\%$ \\
\hline Pain in abdomen (n-18) & 3 & 16.66 & 4 & 22.22 & 6 & 33.33 & 13 & 72.22 & 5 & 27.77 \\
\hline Vomiting (n-17) & 8 & 47.05 & 3 & 17.64 & 4 & 23.52 & 15 & 88.23 & 2 & 11.76 \\
\hline $\begin{array}{l}\text { Burning in micturition } \\
\text { (n-20) }\end{array}$ & 6 & 30 & 5 & 25 & 2 & 10.0 & 15 & 75 & 5 & 25 \\
\hline
\end{tabular}

Table 5: Effect of forced Diuresis on the Patients of multiple site urinary Calculi (No. of Cases = 25)

\begin{tabular}{|c|c|c|c|c|c|c|c|}
\hline \multirow{3}{*}{$\begin{array}{l}\text { No. of Pus } \\
\text { Cells/HPF }\end{array}$} & \multirow{3}{*}{ Total } & \multicolumn{6}{|c|}{ Number of Cases } \\
\hline & & \multicolumn{2}{|c|}{$1^{\text {st }}$ Cycle } & \multicolumn{2}{|c|}{$2^{\text {nd }}$ Cycle } & \multicolumn{2}{|c|}{$3^{\text {rd }}$ Cycle } \\
\hline & & No. & $\%$ & No. & $\%$ & No. & $\%$ \\
\hline$<6$ & 11 & 08 & 72.72 & 3 & 27.28 & 0 & -- \\
\hline $6-10$ & 31 & 21 & 67.74 & 6 & 19.35 & 4 & 12.90 \\
\hline Loaded & 79 & 43 & 55.43 & 21 & 26.58 & 15 & 18.98 \\
\hline Total & 121 & 72 & 59.50 & 30 & 24.79 & 19 & 15.70 \\
\hline
\end{tabular}

As it is evident from the above table that after all three cycles of forced diuresis, urine microscopic examination showed gradual decline of pus cells in the urine with corresponding relief of symptoms.

\begin{tabular}{|c|c|c|c|c|c|c|c|c|}
\hline \multirow{3}{*}{$\begin{array}{l}\text { Effect of forced } \\
\text { Diuresis }\end{array}$} & \multicolumn{6}{|c|}{ Number of Cases } & \multirow{2}{*}{\multicolumn{2}{|c|}{$\begin{array}{l}\text { Total No. of Cases } \\
\text { after Three Cycles }\end{array}$}} \\
\hline & \multicolumn{2}{|c|}{$\begin{array}{l}1^{\text {st }} \text { Cycle } \\
(n=25)\end{array}$} & \multicolumn{2}{|c|}{$\begin{array}{c}2^{\text {nd }} \text { Cycle } \\
(n=20)\end{array}$} & \multicolumn{2}{|c|}{$\begin{array}{c}3^{\text {rd }} \text { Cycle } \\
(n=16)\end{array}$} & & \\
\hline & No. & $\%$ & No. & $\%$ & No. & $\%$ & No. & $\%$ \\
\hline Descent & 3 & 12.0 & 2 & 10.0 & 2 & 12.5 & 7 & 28.0 \\
\hline Passed & 2 & 8.0 & 2 & 10.0 & 5 & 31.25 & 9 & 36.0 \\
\hline No Effect & 20 & 80.0 & 16 & 80.0 & 9 & 56.25 & 9 & 36.0 \\
\hline & & fect o & $\begin{array}{l}\text { orce } \\
\text { of } S\end{array}$ & $\begin{array}{l}\text { Diur } \\
\text { ne in }\end{array}$ & $\begin{array}{l}\text { is on } \\
\text { atien }\end{array}$ & $\begin{array}{l}\text { he Des } \\
\text { s of Ur }\end{array}$ & $\begin{array}{l}\text { ent }(A \\
\text { eric } C\end{array}$ & KUB) or \\
\hline
\end{tabular}

\begin{tabular}{|c|c|c|c|c|}
\hline Sl. No. & Treatment & No. of Cases & Percentage \\
\hline \multirow{3}{*}{1} & \multirow{3}{*}{ Operative } & Pyelolithotomy & 10 & 16.12 \\
\cline { 3 - 5 } & & Nephrectomy & 2 & 3.22 \\
\cline { 3 - 4 } & Neprolithotomy & 1 & 1.61 \\
\hline 2 & Conservative treatment & 49 & 79.03 \\
\hline \multicolumn{3}{|c|}{ Total } & $\mathbf{6 2}$ & $\mathbf{1 0 0 . 0}$ \\
\hline \multicolumn{3}{|c|}{ Table 8: Different treatment procedures for cases of renal calculus (n= 62) } \\
\hline
\end{tabular}

\begin{tabular}{|c|c|c|c|c|}
\hline Sl. No. & \multicolumn{2}{|c|}{ Treatment } & No. of Cases & Percentage \\
\hline 1 & Operative & Ureterolithotomy & 05 & 20.0 \\
\hline 2 & \multicolumn{2}{|c|}{ Conservative treatment } & 20 & 80.0 \\
\hline \multicolumn{3}{|c|}{ Total } & 25 & 100 \\
\hline & \multicolumn{3}{|c|}{ Table 9: Different treatment procedures for cases of ureteric calculus (n= 25) } \\
\hline
\end{tabular}

\begin{tabular}{|c|c|c|c|c|}
\hline $\begin{array}{l}\text { Sl. } \\
\text { No. }\end{array}$ & \multicolumn{2}{|r|}{ Treatment } & No. of Cases & Percentage \\
\hline \multirow{3}{*}{1} & \multirow{3}{*}{ Operative } & Suprapubic cystolithotomy & 76 & 86.36 \\
\hline & & $\begin{array}{l}\text { Suprapubic cystolithotomy with } \\
\text { suprapubic prostectomy }\end{array}$ & 04 & 4.54 \\
\hline & & Cystolithotomy & 02 & 2.27 \\
\hline \multirow[t]{2}{*}{2} & & Conservative treatment & 06 & 6.81 \\
\hline & & Total & 88 & 100.0 \\
\hline \multicolumn{5}{|c|}{ Table 10: Different treatment procedures for cases of Vesical calculus $(n=88)$} \\
\hline
\end{tabular}




\begin{tabular}{|c|c|c|c|c|}
\hline $\begin{array}{l}\text { Sl. } \\
\text { No. }\end{array}$ & \multicolumn{2}{|r|}{ Treatment } & $\begin{array}{l}\text { No. of } \\
\text { Cases }\end{array}$ & Percentage \\
\hline \multirow{4}{*}{1} & \multirow{4}{*}{ Operative } & Meatal dilatation with extraction of stone & 1 & 14.28 \\
\hline & & $\begin{array}{l}\text { Stone pushed into urinary bladder and } \\
\text { then S.P. cystolithotomy }\end{array}$ & 2 & 28.57 \\
\hline & & Cystolitholapaxy & 2 & 28.57 \\
\hline & & Ureterolithotomy & 2 & 28.57 \\
\hline & \multicolumn{2}{|r|}{ Total } & 7 & 100 \\
\hline
\end{tabular}

\begin{tabular}{|c|c|c|c|c|c|c|c|}
\hline \multirow{3}{*}{$\begin{array}{l}\text { No. of Pus } \\
\text { Cells/HPF }\end{array}$} & \multirow{3}{*}{ Total } & \multicolumn{6}{|c|}{ Number of Cases } \\
\hline & & \multicolumn{2}{|c|}{$1^{\text {st }}$ Cycle } & \multicolumn{2}{|c|}{$2^{\text {nd }}$ Cycle } & \multicolumn{2}{|c|}{$3^{\text {rd }}$ Cycle } \\
\hline & & No. & $\%$ & No. & $\%$ & No. & $\%$ \\
\hline$<6$ & 11 & 08 & 72.72 & 3 & 27.28 & 0 & -- \\
\hline $6-10$ & 31 & 21 & 67.74 & 6 & 19.35 & 4 & 12.90 \\
\hline Loaded & 79 & 43 & 55.43 & 21 & 26.58 & 15 & 18.98 \\
\hline Total & 121 & 72 & 59.50 & 30 & 24.79 & 19 & 15.70 \\
\hline
\end{tabular}

Table 12: Effect of Different cycles of Forced Diuresis on the Urine Microscopic Examination (n-121)

\begin{tabular}{|c|c|c|c|c|c|}
\hline Sl. No. & $\begin{array}{l}\text { Type of } \\
\text { Stone }\end{array}$ & $\begin{array}{l}\text { No. of } \\
\text { Stone }\end{array}$ & $\begin{array}{c}\text { Conservative } \\
\text { Treatment }\end{array}$ & $\begin{array}{l}\text { Operative } \\
\text { Treatment }\end{array}$ & No. \\
\hline \multirow{3}{*}{1} & \multirow{3}{*}{$\begin{array}{l}\text { Renal } \\
\text { Stone }\end{array}$} & \multirow{3}{*}{62} & \multirow{3}{*}{49} & Pyelithotomy & 10 \\
\hline & & & & Nephrolithotomy & 01 \\
\hline & & & & Nephrectomy & 02 \\
\hline 2 & $\begin{array}{l}\text { Ureteric } \\
\text { Stone }\end{array}$ & 25 & 20 & Urethrolithotomy & 05 \\
\hline \multirow{3}{*}{3} & \multirow{3}{*}{$\begin{array}{l}\text { Vesical } \\
\text { Stone }\end{array}$} & \multirow{3}{*}{88} & \multirow{3}{*}{06} & Suprapubic cystolithotomy & 76 \\
\hline & & & & $\begin{array}{l}\text { Suprapubic cystolithotomy with } \\
\text { Prostectomy }\end{array}$ & 04 \\
\hline & & & & Cystolitholepexy & 02 \\
\hline \multirow{4}{*}{4} & \multirow{4}{*}{$\begin{array}{l}\text { Urethral } \\
\text { Stone }\end{array}$} & \multirow{4}{*}{7} & \multirow{4}{*}{-} & Meatal dilatation with extraction of stone & 1 \\
\hline & & & & $\begin{array}{l}\text { Stone pushed into urinary bladder and } \\
\text { then S.P. cystolithotomy }\end{array}$ & 2 \\
\hline & & & & Cystolitholapaxy & 2 \\
\hline & & & & Urethrolithotomy & 2 \\
\hline \multirow{6}{*}{5} & \multirow{5}{*}{$\begin{array}{c}\text { Multiple } \\
\text { Site }\end{array}$} & \multirow{5}{*}{25} & \multirow{5}{*}{14} & Pyelithotomy & 2 \\
\hline & & & & Urethrolithotomy & 2 \\
\hline & & & & Suprapubic cystolithotomy & 5 \\
\hline & & & & $\begin{array}{l}\text { Suprapubic cystolithotomy with } \\
\text { Prostectomy }\end{array}$ & 01 \\
\hline & & & & Cystolithotomy & 1 \\
\hline & Total & 207 & 89 & & 118 \\
\hline \multicolumn{6}{|c|}{ Table 13: Summary of treatment of various calculi } \\
\hline
\end{tabular}

\begin{tabular}{|c|c|c|c|c|c|}
\hline \multirow{2}{*}{ Sl. No. } & \multirow{2}{*}{ Treatment } & \multicolumn{2}{|c|}{ s<1 week } & \multicolumn{2}{|c|}{ 1-2 weeks } \\
\hline & & No. & $\%$ & No. & $\%$ \\
\hline 1. & Operative $(n=118)$ & 12 & 5.79 & 106 & 51.20 \\
\hline 2. & Conservative $(n=89)$ & 80 & 38.64 & 09 & 4.34 \\
\hline & otal $(n=207)$ & 92 & 44.44 & 115 & 55.66 \\
\hline
\end{tabular}

\section{DISCUSSION AND RESULTS}

Urinary calculi are third most common condition of urinary system, exceeded only by the urinary tract infection and pathological conditions of the prostate.

The etiology of stones remains speculative. The incidence varies with age, sex, socio-economic status, diet, racial factors and geographical factors.

Recurrence and its management is still a great problem, although in last ten years due to the development of newer methods of treatment for urinary calculi it has now become possible to treat urinary stones without surgery. Medications are available that can help to prevent recurrence of calculi to some extent.

The urine routine and microscopic examination and urine culture gives the information regarding the urinary tract infection in causation of calculus formation. 
Dietary analysis in cases of vesical calculus gives information about various properties of different foods. Some are calculogenic, while the others are helpful in preventing this by various ways. This information may be of use in decreasing the incidence and specially recurrence of stones.

\section{Incidence}

In the present study, the incidence of radiological confirmed cases of urinary calculus disease were $2.69 \%$ of the total hospital admissions in surgical wards. The incidence of urinary calculi observed by the P.P. Singh et al. (1978). ${ }^{2}$ was (11.4\%); Peter Huges et al. $^{3}$ (6-9\%) and G.R. Shakya (1997). ${ }^{4}$ from Rewa (2.26\%). Maximum number of cases were admitted in the month of Feb. $23 \%$ cases $(11.11 \%)$ and Nov. 21 cases $(10.14 \%)$.

\section{Age Incidence}

In the present study, highest incidence of cases of urinary calculi was seen in age group 21-30 years, 65 cases (21.67\%) followed by age group 0-10 years, 60 cases $(20.78 \%)$. Youngest patient seen in the study was 3 years male and oldest was 80 years male.

\section{Sex Incidence}

In the present study, majority of the cases of urinary calculi were male 151 cases (72.95\%) and female were 56 cases (27.05\%).

\section{Residence}

In the present study majority of the cases belonged to the rural areas 132 cases (84.54\%) and urban 37 cases (15.46). Observations have been reported by various authors Pradeep Soni. ${ }^{5}$ (1997) 65\%, Mahendra Pratap Singh. 6 (89.85\%), Amit Pratap Singh.7 (66.67\%) and Alberto Trinchieri. ${ }^{8}$ (2008) 78.2\%. (1971) observed that stones are more common in rural population than urban. It may be related to protein deficiency, vitamin deficiency, poor hygiene, malnutrition and low socio-economic status in rural areas.

In the present study, most of the patients were vegetarians 115 cases (55.55\%) and consumed wheat as a staple food. Numerous clinical and experimental observations have emphasized the relationship between stone formation and deficiency of certain essentials in diet. Vitamin " $A$ " deficiency, pyridoxin deficiency, trace element deficiency and low protein diet, all are associated with increased incidence of stone formation (Kancha et al. 1992). ${ }^{9}$

\section{Site of Stone}

In the present study, majority of cases diagnosed on the basis of Radiological confirmation were of lower urinary tract $(45.89 \%)$ cases; of which most of the cases were of bladder stones 88 cases (42.51\%).

Upper urinary tract calculi were most common in middle age groups; renal stones in 21-30 years $(46.51 \%)$, ureteric stones in $21-30$ years $(18.60 \%)$. In lower urinary tract calculi, bladder stone were most common in lower age groups; in 1-10 years (86.66\%).

\section{CLINICAL FEATURES}

\section{Symptoms}

In the present series major complaints were pain in abdomen 161 cases $(77.77 \%)$, burning micturition 133 cases (62.25\%), frequency of micturition 114 cases (55.07\%), vomiting 83 cases $(40.09 \%)$ and dribbling or feeble stream of urine 79 cases $(38.16 \%)$.

In renal calculus patients, most common complaint was pain in abdomen 42 cases (67.74\%), followed by vomiting 39 cases $(61.29 \%)$ and burning micturition 20 cases $(32.25 \%)$.

In urethral calculus patients, most common complaint was pain in abdomen 20 cases (80\%) followed by vomiting 16 cases (64\%) and burning micturition 9 cases (36\%).

In vesical calculus patient, most common complaint was frequency of micturition 82 cases $(93.18 \%)$, followed by burning micturition 78 cases (88.60\%), dribbling or feeble stream of urine 68 cases (77.27\%).

In urethral calculus patients, most common complaints were pain in abdomen, burning micturition in 5 cases $(71.2 \%)$ and dribbling or feeble stream of urine and retension of urine in 7 cases $(100 \%)$ each.

As seen from the above observation, majority of the patients presented with pain and burning micturition. Pain in cases of renal and ureteric calculus is due to increased intraluminal pressure; while in vesical calculus due to irritation of the bladder wall, burning in micturition is suggestive of associated urinary tract infection.

\section{Signs}

In the present series, main physical signs in patients of vesical calculus were distension of bladder 40 cases $(45.45$ $\%)$, palpable stones in urinary bladder 19 cases (21.59\%) and rectal prolapse 8 cases $(9.09 \%)$. Associated BPH was found in 24 cases $(27.27 \%)$.

Stone was palpable in the bladder by bimanual examination in the cases, where the size of stone was more than $3 \mathrm{~cm}$. Distended bladder was seen in either impacted urethral or impacted vesical calculus or very large calculus or enlarged prostate with associated vesical calculus. The rectal prolapse in some patients was because of excessive straining during micturition.

\section{Urine Microscopic Examination}

In present study, on urine routine and microscopic examination Pus cells were positive in 109 cases (52.62\%) followed by RBCs 147 cases (71.01\%) and casts 88 cases $(42.51 \%)$. Pus cells are indicative of urinary tract infection and $>6$ pus cells/HPF is significant. Presence of RBCs indicate haematuria due to erosions by rough or spiculated stone. Casts are suggestive of the calculus present in the urinary tract.

\section{Urine Culture}

In the present study, the culture of urine for micro-organisms was positive in 35 cases $(70 \%)$. Most common organism was E. coli cases (38.88\%) followed by staphylococcus aureus 10 cases $(9.0 \%)$ Klebsiella 6 cases $(6.66 \%)$. Urine was sterile in 64 cases $(40.76 \%)$.

\section{Effect of Forced Diuresis}

Principally all urinary tract stone should be treated conservatively. Expectant line of treatment is directed towards increased fluid intake avoidance of predisposing factor, dietary modification and drugs to relieve pain. 
In our study forced diuresis given in all 207 patients and after giving treatment, relief in symptoms, any descent or passage of urinary stone or any changes in urine routine and microscopic examination was noted and compared.

In cases of renal calculi, pain in abdomen was relieved in 23 cases (57.5\%), vomiting in 24 cases $(70.58 \%)$ and burning in micturition in 16 cases (80.0\%) after all the three cycles of forced diuresis. Thus it is observed that in cases of renal calculi, burning micturition was relieved remarkably more in patients who were given forced diuresis. (Table 2).

In cases of ureteric calculi, pain in abdomen was relieved in 16 cases (80\%), vomiting in 14 cases (87.5\%) and burning in micturition in 7 cases (77.7\%) after all the three cycles of forced diuresis. Thus it is observed that in cases of urethral calculus, vomiting was relieved remarkably more in patients who were given forced diuresis. (Table 3).

In cases of vesical calculus, frequency of micturition was relieved in $34(41.46 \%)$ cases, burning in micturition in $53(67.94 \%)$ cases, stream in $12(17.91 \%)$ cases, pain in abdomen in $35(81.39 \%)$ cases, and haematuria in $18(100 \%)$ cases, after all the three cycles of forced diuresis. Thus it is observed that in cases of vesical calculus, haematuria and pain in abdomen were relieved remarkably more in patients who were given forced diuresis. (Table 4).

Urinary tract infection is another important factor responsible for burning micturition. In the present study, the effect of forced diuresis in flushing out the urinary infection is assessed by urine microscopic examination, i.e. number of pus cells/HPF after each cycle. Less than 5 pus cells/HPF is insignificant and can be present in a normal sample of urine. Therefore, in this study, pus cells was taken +ve when it exceeded 5/HPF and were divided into two groups: 6-10 pus cells/HPF and loaded (i.e. $>10$ pus cells/HPF). After giving all the three cycles of forced diuresis, number of cases with $>6$ pus cells/HPF was (12.90\%) and loaded in 15(18.98\%) cases.

In this study after all the three cycles of forced diuresis, the stone descended down in 7 cases (28\%) and passed out in 9 cases (36\%). (Table 12).

This process of descent or passage of stone can be facilitated by relaxing the smooth muscle of ureter and then forcefully pushing down the increased amount of urine down the ureter, so that the stone obstructing the ureter is also pushed down and subsequently passed out. In the present study this has been done by using IV fluids Ringer lactate, which increases the amount of urine formation; IV Hyoscine butylbromide and hydroxyprogesterone which relaxes the smooth muscles of ureter and IV Furosemide, which forcefully pushes the increased amount of urine down the relaxed ureter.

The patient of urinary calculus usually receive various treatment of different and usually report late when stone becomes large and causes severe symptom due to obstruction. These patients are treated for acute symptoms and are subjected to various surgical procedures depending upon and size of stone.

\section{Renal Calculus}

Out of 62 cases of renal calculus, 13 cases were treated surgically in the present study. Out of these 13 cases, 10 $(16.12 \%)$ were treated by Pyelolithotomy, 1 cases $(1.61 \%)$ were treated by Nephrolithotomy, 2 cases (3.22\%) were treated by Nephrectomy. The remaining 49 cases (79.03\%) were treated conservatively.

Pyelolithotomy was done for stones present in renal pelvis. Nephrolithotomy was done for large complex staghorn calculus branching into peripheral calyces. Nephrectomy was done in the cases where kidney was completely destroyed by obstruction and infection.

\section{Ureteric Calculus}

In the present study, out of 25 cases only 5 cases of ureteric stone was treated by ureterolithotomy, whereas remaining 20 cases were treated by expected line of treatment. Maximum number of patients of ureteric colic got symptomatic relief after conservative treatment and were discharged and advised to attend SOPD for followup.

\section{Vesical Calculus}

In the present study out of 88 cases, $76(86.36 \%)$ cases of bladder stones were treated by suprapubic cvstolithotomv. 4 cases $(4.54 \%)$ were treated by suprapubic cystolithotomy with prostectomy and 2 cases were treated with Cystolitholapexy. The remaining 6 cases $(6.68 \%)$ of vesical calculus had either taken discharge on request or were not fit for surgery.

\section{Urethral Stones}

In the present study out of 7 cases, 2 cases (28.57\%) stone was pushed through the urethra into the bladder and then suprapubic cystolithotomy was performed. In 2 cases $(28.57 \%)$ urethrolithotomy was done, litholapexy was done in 2 cases $(28.57 \%)$ and $1(14.28 \%)$ cases were treated by meatal dilatation with extraction of stone.

In cases where the stone was in the distal urethra, it was brought near the external urethral orifice by milking and was extracted after meatal dilatation. In cases of stone in the posterior urethra or stone above the penile part of urethra, it was pushed inside the bladder with the help of lubricating jelly and subsequent suprapubic cystolithotomy was performed.

\section{Complications Following Surgery}

In the present study, complications were found in $25(21.18 \%)$ cases of all operated cases. Most common complication following surgery was suprapubic leakage 8 cases $(6.77 \%)$ followed by haematuria 7 cases $(5.93 \%)$, wound gapping 5(4.23\%) and wound infection 5(4.23\%).

Suprapubic urinary leakage was associated with suprapubic cystolithotomy. Possible contributing factors to this were the presence of urinary tract infection, early removal of periurethral catheter, little immobilization. All cases of urinary leakage were treated conservatively. Catheter was introduced per urethra and dressing and strapping of suprapubic wound was done and the patients was mobilized. Cases responded well to the conservative treatment.

Wound gapping usually occurs if wound infection is present or stitches after surgery are removed early in an undernourished patient. Primary aim is to control infection, so that the gap itself fills up. If not then secondary suturing can be done.

Cases of haematuria were treated by local anticoagulant agents, dressing and proper antibiotics. 
In majority of the centres, open surgical procedure are done with comparable results. Endosurgery in management of urinary calculi have reduced hospital stay, postoperative pain and rate of complications.

Urolithiasis is the most common urinary tract problem which is due to poor water intake, excessive consumption of oxalate, calcium and other crystals, ascending or systemic infection or obstruction to urinary passage either alone or in combination.

Acute symptoms in urolithiasis are primarily because of superimposed infection or passage of the stone. Forced diuresis results into dilution of urine, which reduces the acute symptoms by diluting the bacterial load and helping in pushing the small sized stones downwards and probably breaking the stone and cleaning the inflammatory deposits.

Kidney stones still present as an important and challenging clinical problem. Medical therapy when used judiciously in conjunction with dietary measures can help in preventing recurrence and in expulsion of small size $(<10 \mathrm{~mm})$ stones. Awareness of the advantages and limitations of different modalities of medical therapy is necessary in order to provide the correct treatment to patients presenting with this common complaint.

It is important to understand that Hypercalciuria and hyperuricosuria seemed to be the most important metabolic factors of calculus forming stone.

It is important that better understanding of the causes of urolithiasis may lead to earlier diagnosis and appropriate treatment of the metabolic diseases and hence prevention of renal damage and recurrences may be possible. In conclusion, urolithiasis should be suspected in young infants presenting with UTI and toddlers presenting with hematuria. In addition atypical urinary symptoms may indicate urinary calculi in areas where they are endemic, so that a high index of suspicion is important for diagnosis.

\section{SUMMARY AND CONCLUSION}

Acute symptoms in urolithiasis are primarily because of superimposed infection or passage of the stone. Forced diuresis results into dilution of urine, which reduces the acute symptoms by diluting the bacterial load and helping in pushing the small sized stones downwards and probably breaking the stone and cleaning the inflammatory deposits.

It is recommended that the acute symptoms in urolithiasis are treated by plenty of oral fluids along with urinary antiseptics and alkalizers. Forced diuresis helps in pushing the stone down and relieving the inflammatory symptoms by urinary dilution.

Kidney stones still present as an important and challenging clinical problem. Medical therapy when used judiciously in conjunction with dietary measures can help in preventing recurrence and in expulsion of small size
$(<10 \mathrm{~mm})$ stones. Awareness of the advantages and limitations of different modalities of medical therapy is necessary in order to provide the correct treatment to patients presenting with this common complaint.

It is important to understand that hypercalciuria and hyperuricosuria seemed to be the most important metabolic factors of calculus forming stone, calculus forming stones in our pediatric series.

It is important that better understanding of the causes of urolithiasis may lead to earlier diagnosis and appropriate treatment of the metabolic diseases, and hence prevention of renal damage and recurrences may be possible. In conclusion, urolithiasis should be suspected in young infants presenting with UTI and toddlers presenting with hematuria. In addition, atypical urinary symptoms may indicate urinary calculi in areas where they are endemic, so that a high index of suspicion is important for diagnosis.

\section{REFERENCES}

1. Mandar Tilak, Nikhil Bhamare. Progesterone hydrotherapy in management of small, mid and lower ureteric calculi International Journal of recent trends in Science and Technology, ISSN 2277-2812 E-ISSN 2249-8109, 2012;4(2).

2. Singh PP, Singh LBK, et al. Urolithiasis in Manipur (North Eastern region of India). Incidence and chemical composition of stones. The American Journal of Clinical Nutrition 31: September 1978, pp. 15 19-1525.

3. Shakya GR, et al. Clinico-bacteriological study of patients of urinary calculi with special reference to culture of stone 1997.

4. Hughes P. Kidney stones epidemiology journal compilation 2007 Asian Pacific Society of Nephrology. Journal compilation (C) 2007 Asian Pacific Society of Nephrology 2007;12,S26-S30.

5. Soni P, et al. "Role of Progesterone in ureteric calculus." APS University, Rewa (MP) April 1997.

6. Singh MP, et al. "Clinico-Bacteriological Study of Vesical Calculus." APS University, Rewa (MP) April 2004.

7. Deora APS. "Clinico-Bacteriological Study of Urinary Calculi with Special Reference to the Role of Forced Diuresis in Relieving Acute Symptoms." APS University, Rewa (MP) April 2006.

8. Trinchieri A. Epidemiology of urolithiasis: an update (dm, gout, preg). Clin Cases Miner Bone Metab. 2008 May-Aug; 5(2):101-106.

9. Kancha RK, Anasuya A. Contribution of vitamin A deficiency to calculogenic risk factors of urine: studies in children. 1992 Feb;47(1):1-9. 